\title{
Research on the Teaching Design of College Entrepreneurship Educational Courses Based on MOOC
}

\author{
Huang Yabin \\ Humanities and Social Sciences College, Heilongjiang Bayi Agricultural University, Daqing, Heilongjiang, 163319, \\ China \\ Email: dqhuanghyb@163.com
}

\begin{abstract}
MOOC has a great influence on current teaching and learning. At present, there are many problems in entrepreneurship education in colleges and universities. This paper expounds the functions and advantages of MOOC and analyzes the feasibility of applying MOOC to the teaching of college students' entrepreneurship educational courses, the realization of sharing course resources and teaching design through MOOC platform. Therefore, the teaching effect of college entrepreneurship education can be improved. Meanwhile, the employment and entrepreneurship ability of college students can be improved.
\end{abstract}

Keywords: MOOC technology, teaching design, college students' entrepreneurship educational courses

\section{Introduction}

Domestic scholars have paid more attention to MOOC technology for many years. In 2013, Tsinghua University, Peking University, Shanghai Jiao Tong University and other universities in China signed cooperation agreements with edX and Coursera, and various universities launched their own MOOC platforms. China has officially entered the period of practical exploration and construction of MOOC[1]. By studying on the integration of MOOC technology and teaching, it can help us to find high-quality teaching strategies based on MOOC that will achieve the goal of optimizing course resources and improving teaching effect.

\section{Theoretical Foundation}

Constructivism holds that learning is a process in which individuals actively construct meaning through interaction with the environment on the basis of existing knowledge and experience. Learning activity is an active process. Each learner encodes new information based on his or her original experience system, and the original knowledge is adjusted and changed due to the entry of new experience. Therefore, the learning process is not a simple input, storage and extraction, but a Two-Way process between old and new experiences [2]. Constructivism is a knowledge system that is closely related to learners' effective construction and their learning experience. The learning theory that the instructor effectively enhances learners' active knowledge construction with the help of the learning platform built by various learning resources[3]. New constructivism proposes that "learning is construction, and construction implies innovation", "learning for innovation, innovation in learning" [4].Therefore, innovation is the ultimate goal of the new constructivism theory, and a series of strategies and modes are built around this core idea.

\section{Current Problems in College Entrepreneurship Education}

\subsection{Limitation of Class Hours of Innovation and Entrepreneurship}

The education of Innovation and entrepreneurship involves a wide range of knowledge areas and requires students to learn actively and autonomously. Generally speaking, Chinese universities pay attention to the professional courses, however, the education of innovation and entrepreneurship is only an effective supplement. The limited number of hours is the main reason that restricts the teaching effect of innovation 
and entrepreneurship education.

\subsection{The Number of Experienced Teachers in Innovation and Entrepreneurship Education is Insufficient}

The basic contents of innovation and entrepreneurship education are closely related to the knowledge of thinking innovation, business operation, enterprise management, etc. The teachers with solid professional knowledge and rich practical experience are qualified for this teaching work and the teaching effect should be the best. According to the teaching contents of innovation and entrepreneurship education, some colleges arrange teachers of related courses to undertake the teaching tasks of innovation and entrepreneurship. For example, teachers majoring in economics are responsible for teaching business operation, while teachers majoring in management are responsible for enterprise management. Although these teachers have certain teaching and scientific research abilities, they lack solid professional knowledge and rich practical experience and cannot promote the further improvement of innovation and entrepreneurship education. Therefore, the teaching cannot truly meet the needs of current innovation and entrepreneurship education in terms of the depth and breadth of knowledge.

\subsection{Resistance from Adapting to a New Situation}

Nowadays, a large number of learners have learned and trained by themselves through MOOC platform. Therefore, the teachers need to rebuild the traditional teaching model, teaching design and contents. This puts forward higher request to the teacher's educational thinking and ability. For students, they need to timely change the traditional learning mode, change to be active, change to obtain knowledge by finding problems actively, and actively participate in the learning and construction of new knowledge, which requires teachers and students to take a long time to adapt and change.

\section{Make Full Use of the Advantages of MOOC Platform}

\subsection{Breaking through the Limitation of Time and Space}

MOOC is free from the time and space limitations of traditional classroom teaching. In particular, in recent years, MOOC technology on mobile terminals has gradually matured, and college students can receive innovation and entrepreneurship education anytime and anywhere by using mobile phones. Students can study independently after class and in winter and summer vacations without taking up too many class hours. In other words, students can effectively use some spare time in their daily life to study, and they can watch the content they don't understand again and again to improve their learning effect. In addition, if students encounter problems in the practice of innovation and entrepreneurship, they can search relevant course resources through the MOOC platform, and find solutions to the problems. At present, MOOC platform provides more and more functions such as online attendance, online live, online examination, project design and project application, which makes it easier to guarantee students' learning effect.

\subsection{Solution to the Problem of Lack of Teachers in Entrepreneurship Education}

Compared with western countries, entrepreneurship education in China started relatively late, and the development of entrepreneurship education courses is not perfect. By sharing teaching resources of famous teachers with the aid of MOOC platform, MOOC solves the problem of shortage of teachers in entrepreneurship education and enables more local universities to share domestic and even global high-quality teaching resources.

\subsection{Promoting the Innovation of Teaching and Evaluation Methods}

MOOC not only has brought the impact of the existing teaching model, but also changed the way to learn, which will make autonomous and interactive teaching possible. Compared with the traditional education 
model, MOOC provides more opportunities for equal dialogue between teachers and students and breaks the shackles of teaching and learning. In addition, MOOC promotes the diversification of evaluation of learning and teaching and students can get timely feedback from their classmates, teachers and experts.

\section{$5 \quad$ The Teaching Design of College Entrepreneurship Educational Courses Based on MOOC}

\subsection{Teaching Contents of the Course in Entrepreneurship Education Based on MOOC}

There are three modules of the course, including entrepreneurship overview, entrepreneurship skills and frontier, entrepreneurship cases and practical training. The course is summarized as follows:

Module 1: entrepreneurship overview

MOOC is mainly used for online teaching and offline tutoring, which introduces the concept, scope and domestic and foreign experience of entrepreneurship, so as to establish students' preliminary understanding of entrepreneurship, such as online entrepreneurship, campus entrepreneurship and social enterprise, etc.

Module 2: entrepreneurship skills and frontier

Online courses of entrepreneurship through MOOC combine with diversified entrepreneurship perspectives, which start with the introduction of WeChat, taobao, crowdfunding and other innovative entrepreneurship tools and platforms, as well as other entrepreneurship related practices in order to cultivate students' entrepreneurship skills.

Module 3: entrepreneurial cases and practical training

Entrepreneurs are invited to introduce entrepreneurship cases and exchange relevant experience, which can guide students to understand social reality and think about entrepreneurship from a more diversified perspective. In addition, it is required to mention the experience of entrepreneurship failure or the detours in the course of business startups, the practical experience of entrepreneurship and its relationship to economics development of China. Meanwhile, the students have more opportunities to participate in practical training of entrepreneurship with entrepreneurs.

\subsection{Teaching Design of the Course in Entrepreneurship Education Based on MOOC}

The teaching design based on MOOC platform conforms to the trend of the information age and can effectively remedy the deficiencies of the traditional teaching mode. The teaching design is based on the following two principles:

(1) students who are really interested in entrepreneurship and have a preliminary awareness of entrepreneurship can be fully selected.

(2) it is necessary to further improve and build a reasonable and scientific evaluation system of teaching effect. That is, how to take students as the center and process evaluation as the main body in this system. Through multi-dimensional and dynamic evaluation of students' learning process, it can better stimulate students' interest and motivation in learning and promote the development of students' independent learning ability.

The contents of teaching design are as follows:

First, in the course of entrepreneur cultivation, through practical cases and MOOC teaching, teachers make students enter the situation of production and management, experience different roles, make different management decisions, make them stand in different angles to think about problems, exercise their thinking ability and basic qualities of entrepreneurs, make them change from perceptual knowledge to rational knowledge. In case teaching, more attention should be paid to the explanation and analysis of failure cases, so that students can understand that the number of failures in actual entrepreneurship practice is far greater than the chance of success. Therefore, students can realize the difficulty and complexity in the early stage of entrepreneurship.

Second, teachers should assign some classic cases in the classroom or let students find data related to this course. In every class, students accomplish case analysis and answer questions each other. In this way, not only it can cultivate the students' self-learning ability, but also improve the students' language expression ability and thinking ability. 
Third, people from the business community and successful entrepreneurs who have started their own businesses should be invited to enter the classroom and give a report on employment and entrepreneurship, share their work experience with students, which will deepen students' understanding of the theories they have learned.

Finally, about the design of the entrepreneurial planning, the entrepreneurial planning is one of key and difficult contents of this course, so after class students must make effort to improve the skill. On the basis of the class team, each group is required to choose a business project and conduct market research, collect data, form a business planning, and make PPT after class. The show of the PPT will be explained in class, and the teacher will comment and score the project.

\section{Conclusion}

With rapid development of education and technology, MOOC has had a huge impact on global education, and its localization in China is in full swing. Colleges and universities should take advantage of the new situation to guide teachers to improve their teaching ability. In other words, teachers play a leading role in teaching reform, and their research and teaching practice promote the process of the innovation of entrepreneurship curriculum construction through MOOC platform. In addition, the production of a set of high-quality courses requires not only the lecturers, but also a number of professors, teaching assistants and courseware design experts behind the platform. The teaching team of entrepreneurship education based on MOOC should be composed of the first-line famous teachers or the experts with entrepreneurship experience. After careful teaching design of entrepreneurship education, teachers who are engaged in entrepreneurship education can provide online counseling, answer questions and assist in teaching reform. Therefore, it is urgent to cultivate a team of excellent teachers in entrepreneurship education. MOOC has provided a great help to optimize the proportion of teaching resources and improve the teaching effect of entrepreneurship education. The MOOC platform is covering all colleges and universities in china and high-quality courses of entrepreneurship education based on MOOC will strongly promote the development of broad-spectrum entrepreneurship education. How to further adjust the training and teaching program and improve the curriculum is worthy of further in-depth research and thinking for innovation and entrepreneurship educators.

\section{References}

1. Ma yun, zheng yanlin, shi huizhan. Research on the current situation of the discipline distribution of MOOC in domestic universities [J]. Modern distance education, 2017, (1): 11-19.

2. Lorenzo F, Leticia Rodríguez. Onset and expansion of L2 cognitive academic language proficiency in bilingual settings: CALP in CLIL[J]. System, 2014, 47:64-72.

3. FengYuFang.2006. The application of six elements of constructivist learning design in English teaching [J].Foreign languages and foreign language teaching (6): 33-36.

4. Shi Wenjia.2017.Design and Development of Wiki-blog Based on New Constructivism and the Policy of Small Savings and Retrieval[J].Knowledge Innovation and Management (4): 42-49.

5. Wang Hairong, zhang Wei. Design Concept and Inspiration of Large-scale Open Education Resources in Foreign Countries -- An Empirical Study of MOOC Courses Based on Coursera [J].Journal of Tianjin TV University. 2013 (3): $32-36$. 